\title{
Diabeteses kisér-károsodás vizsgálata optikai koherencia tomográfián alapuló angiográfiával
}

\author{
Czakó Cecília dr. - Sándor Gábor László dr. - Ecsedy Mónika dr. \\ Szepessy Zsuzsanna dr. - Borbándy Ágnes dr. - Resch Miklós dr. \\ Papp András dr. - Récsán Zsuzsa dr. - Horváth Hajnalka dr. \\ Nagy Zoltán Zsolt dr. - Kovács Illés dr.
}

Semmelweis Egyetem, Általános Orvostudományi Kar, Szemészeti Klinika, Budapest

\begin{abstract}
Bevezetés: Az optikai koherencia tomográfián alapuló angiográfia új noninvazív eszköz, amely lehetővé teszi a retinalis érhálózat vizsgálatát, és segítséget nyújthat a microangiopathiával járó szemfenéki betegségek nyomon követésében. Célkitüzés: Diabeteses betegek mindkét szemén optikai koherencia tomográfiás angiográfiával meghatározni a retinalis kisér-károsodás mértékét az általános rizikófaktorok függvényében.

Módszer: Optikai koherencia tomográfiás angiográfia során 36 diabeteses, valamint 45 kontrollszemély mindkét szemén meghatároztuk a retinalis érhálózat sürüségét. Rögzítettük a magas vérnyomást, a diabetes fennállási idejét, az inzulinkezelést, a $\mathrm{HbA}_{1 \mathrm{c}}$-szintet, a dyslipidaemia és a diabeteses retinopathia jelenlétét, továbbá a szem tengelyhoszszát. A rizikófaktoroknak az érhálózat-sürúségre és a két szem közötti aszimmetriára kifejtett hatását többváltozós regressziós modellekben vizsgáltuk.

Eredmények: Diabeteses betegekben a retinalis érhálózat sưrúsége szignifikánsan alacsonyabb volt, mint kontrollszemélyekben $(\mathrm{p}<0,05)$, és ugyanazon beteg két szemének adatai között mért különbség szignifikánsan magasabb volt, mint a kontroll egészséges személyek két szeme között mért különbség $(\mathrm{p}<0,05)$. Mind a retinalis érsürüség, mind a két szem közötti aszimmetria korrelált a diabetes fennállási idejével $(\mathrm{p}<0,05)$, kontroll alatt tartva az általános rizikófaktorok hatását. A kontrollcsoporttal összehasonlítva a két szem közötti aszimmetria mértéke szignifikánsan magasabb volt olyan diabeteses betegek két szeme között is, akiknél a diabeteses retinopathia szemfenéki jelei nem voltak láthatók $(\mathrm{p}<0,001)$.

Következtetések: Diabeteses betegekben csökkent az érhálózat sưrúsége egészséges személyekkel összehasonlítva, továbbá fokozott a két szem közötti aszimmetria. A csökkent érhálózat-sűrűség és a két szem közötti fokozott aszimmetria a betegség fennállási idejével arányos, és alkalmas lehet a diabeteses retinopathia igen korai, szemfenékvizsgálattal még nem látható formáinak kiszưrésére, így segítve a terápia mielőbbi megkezdését.
\end{abstract}

Orv Hetil. 2018; 159(8): 320-326.

Kulcsszavak: optikai koherencia tomográfián alapuló angiográfia, diabeteses retinopathia

\section{Evaluation of diabetic microangiopathy using optical coherence tomography angiography}

Introduction: Optical coherence tomography angiography is a non-invasive imaging technique that is able to visualize the different retinal vascular layers using motion contrast to detect blood flow without intravenous dye injection. This method might help to assess microangiopathy in diabetic retinopathy during screening and follow-up.

Aim: To quantify retinal microvasculature alterations in both eyes of diabetic patients in relation to systemic risk factors using optical coherence tomography angiography.

Method: Both eyes of 36 diabetic patients and 45 individuals without diabetes were examined. Duration of diabetes, insulin therapy, blood pressure, $\mathrm{HbA}_{\mathrm{lc}}$, dyslipidemia, axial length and the presence of diabetic retinopathy were recorded. Retinal vessel density was measured by optical coherence tomography angiography. The effect of risk factors on vessel density and between-eye asymmetry was assessed using multivariable regression analysis.

Results: Vessel density was significantly lower and between-eye difference was significantly higher in diabetic patients compared to controls $(\mathrm{p}<0.05)$. Both vessel density and between-eye asymmetry significantly correlated with diabetes duration $(\mathrm{p}<0.05)$ after controlling for the effect of risk factors. The between-eye asymmetry in vessel density was significantly higher in patients without clinically detectable diabetic retinopathy compared to control subjects $(\mathrm{p}<0.001)$. 
Conclusions: There is a decrease in retinal vessel density and an increase in between-eye asymmetry in patients with diabetes compared to healthy subjects. By using optical coherence tomography angiography, the detection of these microvascular alterations is possible before clinically detectable diabetic retinopathy and might serve as a useful tool in both screening and timing of treatment.

Keywords: optical coherence tomography angiography, diabetic retinopathy

Czakó C, Sándor GL, Ecsedy M, Szepessy Zs, Borbándy Á, Resch M, Papp A, Récsán Zs, Horváth H, Nagy ZZs, Kovács I. [Evaluation of diabetic microangiopathy using optical coherence tomography angiography]. Orv Hetil. $2018 ; 159(8): 320-326$.

(Beérkezett: 2017. október 10.; elfogadva: 2017. november 4.)

\section{Rövidítések}

DR = diabeteses retinopathia; OCT $=$ optikai koherencia tomográfia; OCTA = optikai koherencia tomográfián alapuló angiográfia

A diabeteses retinopathia (DR) a diabetes mellitus egy gyakori kisér-károsodással járó szövődménye, mely a betegek közel $80 \%$-át érinti a betegség 15 éves fennállását követően $[1,2]$. A DR negatív hatással van az életminőségre, elsősorban a látásromlást okozó formáiban (súlyos nem proliferatív DR, proliferatív DR és klinikailag szignifikáns maculaoedema) [3], ami jelentôs terhet ró a társadalomra mind a betegség szűrését, mind a kezelését illetően. Egy közelmúltban hazánkban végzett vizsgálat szerint a diabetes elöfordulása jelentősen nő [4]. A diabetesben kialakuló kisér-károsodás a kapilláriskeringés kieséséhez, ischaemiához vezet, és fokozza az éreredetû növekedési faktor termelődését, ami aztán kóros érújdonképződéshez és fokozott érpermeabilitáshoz vezet [5]. A diabeteses maculopathia - mely a diabeteses retinopathia bármelyik stádiumában kialakulhat - felel a világszerte mért vakság 4,8\%-áért [6].

Régóta ismert tény a nem megfelelő glykaemiás kontroll és a DR kifejlődése, illetve progressziója közötti kapcsolat [7]. Hasonlóképpen, a magas vérnyomás és a dyslipidaemia is a diabeteses retinopathia és a diabeteses maculaoedema ismert rizikófaktorai, noha az összefüggés gyengébb, mint a hyperglykaemia esetében [8-10]. Ezen epidemiológiai és klinikai adatok alapján a jelenlegi terápiás irányelvek e rizikófaktorok szoros kontrollját javasolják $[11,12]$.

A diabeteses betegek közül nagyon fontos azon esetek felismerése, akiknél a látásromlást okozó szövődmények kialakulására fokozott a rizikó. A szemészeti képalkotó vizsgálatok régóta meghatározó szerepet játszanak a diabeteses retinopathia szürésében és követésében. A fluoreszcens angiográfia még ma is arany standard vizsgálat a retina perfúziójának és az ischaemiás károsodásoknak a kimutatására. Az optikai koherencia tomográfián alapuló angiográfia (OCTA) egy új, noninvazív vizsgálómód- szer, mely lehetővé teszi, hogy a már ismert, nagy felbontású keresztmetszeti OCT-képek mellett egyidejűleg képet alkossunk a retinalis és a chorioidealis erek hálózatáról is. A fluoreszcens angiográfiás vizsgálattal szemben az OCT-angiográfiás vizsgálat gyorsan elvégezhető, nem igényel intravénás kontrasztanyag-beadást, így a retina betegségeinek követésére gyakrabban és mellékhatások nélkül alkalmazható. A vizsgálat a mozgáskontraszt elvén múködik, melynek alapja, hogy az egymást rövid időn belül követő leképezések során a nem mozgó retinaszövettől a retina érhálózata elkülöníthető az erekben áramló vörösvértestekről visszaverődött jelek amplitúdójának mérésével. A múszer Angio Analytics szoftvere lehetôséget nyújt a vizsgált terület kvantitatív analízisére, számszerű adatokat szolgáltatva a véráramlásban jelen lévő (flow area) és az áramlásból kiesett területek (nonflow area) nagyságáról, valamint a kapillárisok sưrüségének (vascularis denzitás) mértékéról. A vascularis denzitás a vizsgált terület erekkel ellátott százalékos arányát jellemzi [13]. Az OCTA megjelenése óta számos tanulmány foglalkozott a retinalis kisér-károsodás vizsgálatával diabeteses betegekben. Ezekben a tanulmányokban jellemzően mikroaneurizmák kialakulását, az érhálózat átépülését, a foveolaris avascularis terület megnagyobbodását és a kapillárisok kitágulását és kanyargóssá válását írták le [14-18]. Ugyanakkor nincs klinikai adat arra vonatkozóan, hogy a diabeteses kisér-károsodás milyen mértékben érinti egyazon beteg két szemét, illetve hogy az eltérő érintettség hátterében milyen általános és szemészeti rizikófaktorok állhatnak. Jelen tanulmányunk célja, hogy diabeteses betegek mindkét szemén OCTangiográfiával meghatározva a retinalis kisér-károsodás mértékét, megvizsgáljuk a két szem közötti különbséget a jól ismert általános és szemészeti rizikófaktorok hatásának figyelembevételével.

\section{Módszer}

A prospektív keresztmetszeti vizsgálatba diabeteses (1-es és 2-es típusú) betegeket, valamint kontroll-, nem diabeteses személyeket válogattunk be a Semmelweis Egyetem 
Szemészeti Klinikájának retinaambulanciáján vizsgált személyek közül. A tanulmány a Helsinki Deklaráció elveinek figyelembevételével, valamint az Intézményi Kutatásetikai Bizottság engedélyével zajlott. Összesen 36 diabeteses beteg 72 szemét (diabeteses csoport) és 45 kontroll egészséges személy 90 szemét (kontrollcsoport) elemeztük. A diabeteses csoportban a diabeteses retinopathia jelenléte alapján a szemeket két csoportba soroltuk az „International Clinical Diabetic Retinopathy Disease Severity Scale of the American Academy of Ophtalmology" beosztást követve [17]. A tanulmányból való kizárási kritériumként szerepelt a korábbi szemmütét, egyéb szembetegségek, mint időskori maculadegeneráció, glaucoma, vitreomacularis betegségek, korábbi anti-VEGF- vagy lézerkezelés, klinikailag szignifikáns lencsehomályok jelenléte, valamint $>6$ dioptria fénytörési hiba. Minden résztvevő részletes szemészeti vizsgálaton esett át, beleértve a Snellen-látóélesség meghatározását, réslámpás és szemfenékvizsgálatot. A vizsgálatban rögzítettük a magas vérnyomást, a diabetes fennállási idejét, az inzulinkezelést, a $\mathrm{HbA}_{\mathrm{lc}}$-szintet, valamint a dyslipidaemia jelenlétét. A szem tengelyhosszát optikai biométerrel (Lenstar LS 900, Haag-Streit USA, Mason, $\mathrm{OH}$, USA) mértük. Az optikai koherencia tomográfiás angiográfiai vizsgálatokat AngioVue OCTA készülékkel (RTVue-XR Avanti, Optovue, Fremont, CA, USA) végeztük. A foveolaris avascularis zóna területét, valamint a felszíni retinalis érhálózat sűrüségét a centrális $3 \mathrm{~mm}$-es területen határoztuk meg az AngioAnalytics szoftver segítségével (1. ábra). A retina vastagsági térképét az OCT-felvételekből a centrális $1 \mathrm{~mm}$-es területen mértük. Az OCT-vizsgálatokat gyakorlott személy végezte; minden szemról egymás után három leképezés készült, a statisztikai analíziseket a három mérés átlagából végeztük. A tanulmányba csak azokat a szemeket vontuk be, amelyeknél a képminőség megfelelően jó volt, és a jelerősségi index (signal strength index, SSI) magasabb volt, mint 50 .

\section{Statisztikai analizis}

A statisztikai teszteket SPSS programmal végeztük (SPSS 23.0, IBM, Armonk, NY, USA). A csoportok közötti összehasonlításra ismétléses ANOVA-tesztet használtunk, miután az ismétléses teszt alkalmazásával lehetővé válik, hogy figyelembe vegyük az egyazon személy két szemének adatai közötti korrelációt. A két szem között mért aszimmetria mértékét a két csoportban kétmintás t-teszttel hasonlítottuk össze. Az általános és a szemészeti változóknak az érhálózat-sűrûségben mért aszimmetriára gyakorolt hatását egy- és többváltozós regressziós analízissel vizsgáltuk. Az a priori módon meghatározott rizikófaktorok között az életkor, a cukorbetegség fennállási ideje, a $\mathrm{HbA}_{\mathrm{lc}}$-szint, a magas vérnyomás, az inzulinkezelés, dyslipidaemia és a szem tengelyhossza szerepelt.
1. táblázat A vizsgált csoportok demográfiai és klinikai jellemzői. Az adatokat átlag \pm szórás formában fejezzük ki

\begin{tabular}{llll}
\hline & $\begin{array}{l}\text { Diabeteses } \\
\text { csoport } \\
(\mathrm{n}=36)\end{array}$ & $\begin{array}{l}\text { Kontrollcsoport } \\
(\mathrm{n}=45)\end{array}$ & $\mathrm{p}$ \\
\hline Életkor (év) & $57,72 \pm 13,08$ & $58,19 \pm 12,89$ & 0,87 \\
\hline Nem (férfi/nó) & $19 / 17$ & $32 / 13$ & 0,73 \\
\hline Diabetes fennállási ideje & $18,22 \pm 10,21$ & &
\end{tabular}

Diabetes fennállási ideje $18,22 \pm 10,21$

(év)

\begin{tabular}{|c|c|c|c|}
\hline $\mathrm{HbA}_{\mathrm{lc}}$-szint $(\%)$ & $7,67 \pm 1,17$ & - & - \\
\hline $\begin{array}{l}\text { Inzulinkezelés } \\
\text { (igen/nem) }\end{array}$ & $27 / 9$ & - & - \\
\hline $\begin{array}{l}\text { Dyslipidaemia } \\
\text { (igen/nem) }\end{array}$ & $23 / 13$ & $6 / 39$ & $<0,001$ \\
\hline $\begin{array}{l}\text { Magas vérnyomás } \\
\text { (igen/nem) }\end{array}$ & $31 / 5$ & $16 / 29$ & $<0,001$ \\
\hline $\begin{array}{l}\text { Szem tengelyhossza } \\
(\mathrm{mm})\end{array}$ & $22,84 \pm 0,84$ & $23,04 \pm 1,04$ & 0,57 \\
\hline $\begin{array}{l}\text { Foveolaris avascularis } \\
\text { zóna területe }\left(\mathrm{mm}^{2}\right)\end{array}$ & $0,32 \pm 0,08$ & $0,28 \pm 0,08$ & 0,03 \\
\hline $\begin{array}{l}\text { Retinalis érhálózat } \\
\text { sürüsége - centrális } \\
1 \mathrm{~mm}(\%)\end{array}$ & $28,75 \pm 5,32$ & $30,87 \pm 5,03$ & 0,006 \\
\hline $\begin{array}{l}\text { Retinalis érhálózat } \\
\text { sû́rúsége - centrális } \\
3 \mathrm{~mm}(\%)\end{array}$ & $47,74 \pm 3,37$ & $50,91 \pm 3,25$ & $<0,001$ \\
\hline Retinavastagság ( $\mu \mathrm{m})$ & $298,86 \pm 99,93$ & $251,44 \pm 18,81$ & 0,002 \\
\hline Látóélesség (Snellen) & $0,87 \pm 0,19$ & $0,97 \pm 0,07$ & 0,006 \\
\hline
\end{tabular}

\section{Eredmények}

A diabeteses és a kontrollcsoport között nem volt statisztikailag szignifikáns különbség az életkor, a nem és a tengelyhossz tekintetében $(\mathrm{p}>0,05,1$. táblázat). A hypertonia és a dyslipidaemia előfordulása szignifikánsan magasabb volt a diabeteses csoportban, mint a kontrollcsoportban $(\mathrm{p}<0,05,1$. táblázat $)$. A diabeteses betegekben a retina vastagsága és a foveolaris avascularis zóna mérete szignifikánsan nagyobb, a retinalis érhálózat sürüsége pedig szignifikánsan alacsonyabb volt, mint a kontroll egészséges szemekben $(\mathrm{p}<0,05,1$. táblázat, 2. ábra). A diabeteses csoportban mért látóélesség szintén szignifikánsan alacsonyabb volt, mint a kontroll egészséges csoportban $(\mathrm{p}<0,001,1$. táblázat).

A retinalis érsürüség a kontrollcsoportban az életkorral, a diabeteses csoportban pedig a diabetes fennállási idejével korrelált $(\mathrm{p}<0,05)$. A két szemen mért adatok hasonlóságát vizsgálva egyazon személy két szemének adatai között szoros korreláció mutatkozott mind a diabeteses, mind a kontrollcsoportban (2. táblázat), ugyanakkor a két szem adatai közötti korreláció minden paraméter tekintetében gyengébb volt a diabeteses, mint a kontrollcsoportban (2. táblázat).

Amennyiben az egyazon személy két szemén mért foveolaris avascularis zóna területét hasonlítottuk össze, a 


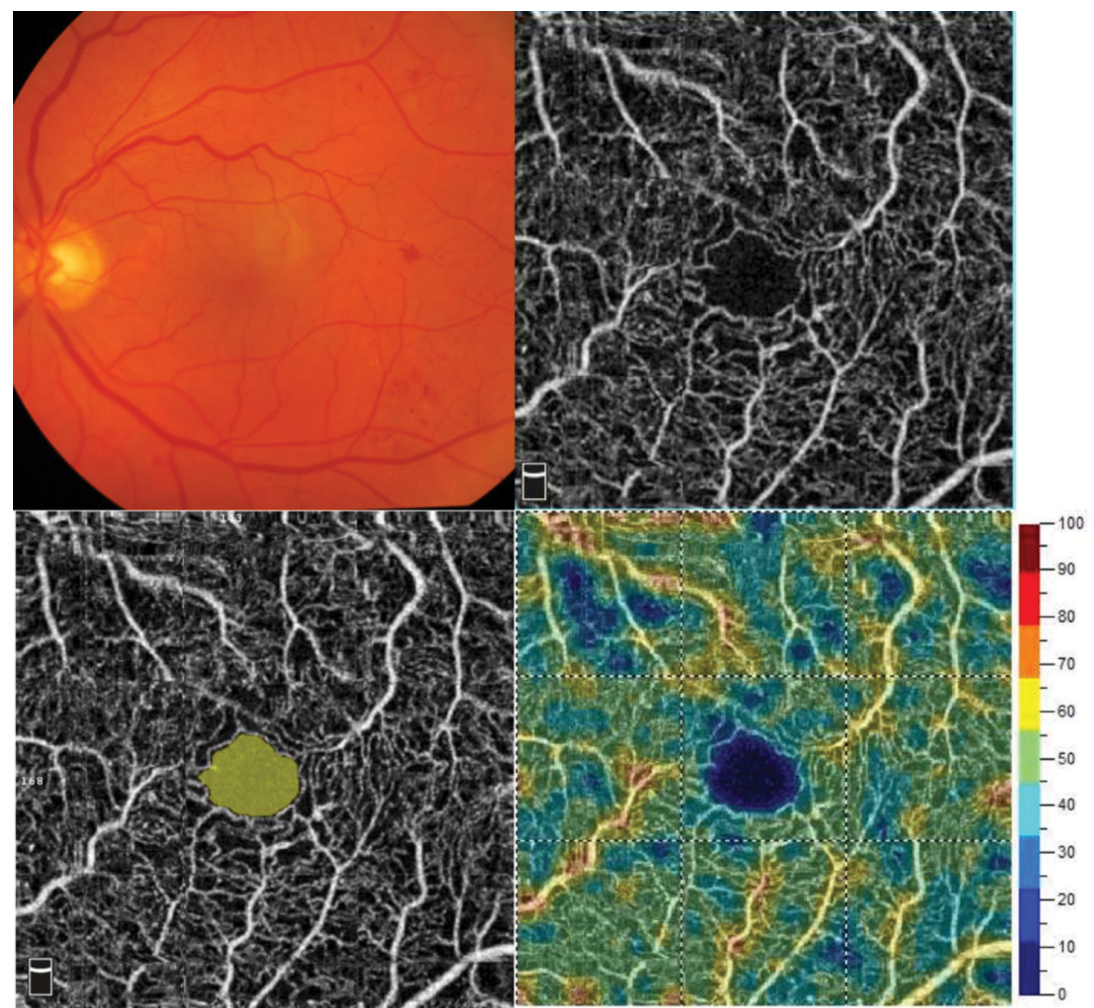

1. ábra

Diabeteses beteg színes szemfenéki felvétele (bal felső kép), valamint OCT-angiográfiás képei az érhálózat áttekintő ábrázolásával (jobb felső kép), a foveolaris avascularis zóna kijelölésével (bal alsó kép) és a retinalis érhálózat sürüségének színkódolt képével (jobb alsó kép) AngioAnalytics szoftver használatával

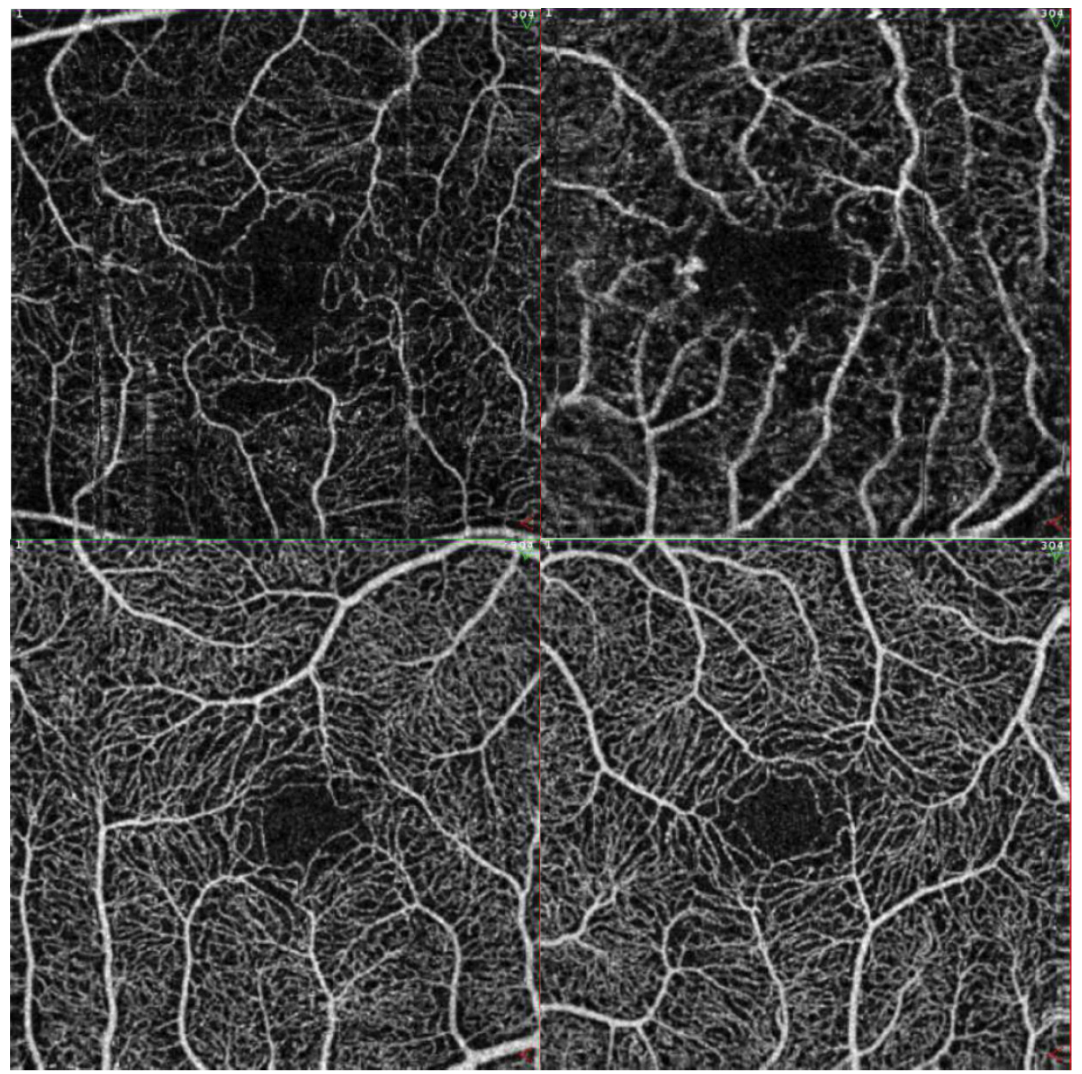

2. ábra $\quad$ Diabeteses beteg (felső képek) és egy kontroll egészséges személy (alsó képek) OCT-angiográfíás felvétele a két szemról. Jól látható diabeteses esetben a kiszélesedett foveolaris avascularis zóna, a csökkent érhálózat-denzitás és a két oldal közötti fokozott aszimmetria a kontrollszemély felvételeivel összehasonlítva 
A két szemen mért adatok közötti korreláció a két csoportban $(\mathrm{r}=$ Pearson-féle korrelációs együttható)

\begin{tabular}{llllll}
\hline & $\begin{array}{l}\text { Diabeteses } \\
\text { csoport } \\
(\mathrm{n}=36)\end{array}$ & $\begin{array}{l}\text { Kontrollcsoport } \\
(\mathrm{n}=45)\end{array}$ \\
\cline { 2 - 6 } & $\mathrm{r}$ & $\mathrm{p}$ & $\mathrm{r}$ & $\mathrm{p}$ \\
\hline $\begin{array}{l}\text { Foveolaris avascularis zóna } \\
\text { területe }\left(\mathrm{mm}^{2}\right)\end{array}$ & 0,77 & $<0,001$ & 0,88 & $<0,001$ \\
\hline $\begin{array}{l}\text { Felszíni retinalis érhálózat } \\
\text { súrúsége - centrális 1 mm }(\%)\end{array}$ & 0,68 & $<0,001$ & 0,81 & $<0,001$ \\
\hline $\begin{array}{l}\text { Felszíni retinalis érhálózat } \\
\text { súrúsége - centrális 3 mm }(\%)\end{array}$ & 0,53 & $<0,001$ & 0,59 & $<0,001$ \\
\hline $\begin{array}{l}\text { Foveolaris avascularis zóna } \\
\text { területe }\left(\mathrm{mm}^{2}\right)\end{array}$ & 0,64 & $<0,001$ & 0,73 & $<0,001$ \\
\hline
\end{tabular}

3. táblázat $\mid$ Az egyazon személy két szemén mért adatok közötti különbség a két vizsgált csoportban. Az adatokat átlag \pm szórás formában fejezzük ki

\begin{tabular}{llll}
\hline & $\begin{array}{l}\text { Diabeteses } \\
\text { csoport } \\
(\mathrm{n}=36)\end{array}$ & $\begin{array}{l}\text { Kontroll- } \\
\text { csoport } \\
(\mathrm{n}=45)\end{array}$ & $\mathrm{p}$ \\
\hline $\begin{array}{l}\text { Foveolaris avascularis zóna } \\
\text { területe }\left(\mathrm{mm}^{2}\right)\end{array}$ & $0,04 \pm 0,03$ & $0,04 \pm 0,03$ & 0,70 \\
\hline $\begin{array}{l}\text { Felszíni retinalis érhálózat } \\
\text { súrúsége }- \text { centrális 1 mm }(\%)\end{array}$ & $3,21 \pm 2,04$ & $2,11 \pm 1,37$ & 0,01 \\
\hline $\begin{array}{l}\text { Felszíni retinalis érhálózat } \\
\text { súrúsége }- \text { centrális 3 mm }(\%)\end{array}$ & $3,02 \pm 2,16$ & $2,16 \pm 1,29$ & 0,004 \\
\hline Retinavastagság $(\mu \mathrm{m})$ & $6,75 \pm 6,36$ & $24,50 \pm 30,42$ & $<0,001$ \\
\hline
\end{tabular}

két csoport között nem találtunk szignifikáns különbséget az aszimmetriában (3. táblázat). Ugyanakkor a diabeteses csoportban az egyazon beteg két szemén mért érhálózat-sűrűségi és retinavastagsági adatok közötti különbség szignifikánsan magasabb volt, mint a kontroll egészséges személyek két szeme között mért különbség (3. táblázat).

A két szem közötti aszimmetria mértéke a kontrollcsoportban nem mutatott összefüggést sem az életkorral, sem a magas vérnyomás vagy a dyslipidaemia jelenlétével, sem a szem tengelyhosszával. Ezzel szemben a diabeteses csoportban az érhálózat-sűrüségben a két szem között mért különbség szignifikánsan korrelált a cukorbetegség fennállási idejével mind egyváltozós regressziós modellben (beta: $0,37,95 \% \mathrm{CI}$ : $0,16-0,42, \mathrm{p}$ : 0,02), mind többváltozós modellben (beta: $0,40,95 \%$ CI: 0,05-0,85 p: 0,04), kontroll alatt tartva az életkor, a $\mathrm{HbA}_{\mathrm{lc}}$, az inzulinkezelés, a hypertonia, a dyslipidaemia és a tengelyhossz hatását.

Végül, a kontrollcsoporttal összehasonlítva a két szem közötti aszimmetria mértéke szignifikánsan magasabb volt olyan diabeteses betegek két szeme között is, akiknél a diabeteses retinopathia szemfenéki és OCT-jelei nem voltak láthatók $(4,19 \pm 2,40 \%$ vs. $2,16 \pm 1,29 \%$, $\mathrm{p}<0,001)$.

\section{Következtetés}

Jelen tanulmányunkban kimutattuk, hogy diabeteses betegekben a két szem retinalis érhálózatának sürüsége jobban eltér, mint a kontroll egészséges személyek két szemén mért értékek. Eredményeink szerint a két szem közötti aszimmetria mértéke egészséges személyekben sem az életkorral, sem a magas vérnyomás vagy a dyslipidaemia jelenlététével, sem a szem tengelyhosszával nem függött össze. Ezzel szemben diabeteses betegekben a két szem közötti aszimmetria a diabetes fennállási idejével arányosan fokozódik, és azt sem a vizsgált általános rizikófaktorok, sem a szem tengelyhossza nem befolyásolja. Tudomásunk szerint jelen vizsgálatunk az első tanulmány, mely a diabeteses retinopathia okozta kisér-károsodás mértékének különbözôségét vizsgálta egyazon beteg két szemének analízisével.

Korábbi tanulmányok eredményeit megerősítve azt találtuk, hogy a felszíni retinalis érhálózat sűrűsége szignifikánsan kisebb diabeteses betegekben, mint a kontroll egészséges személyekben. Eredményünk, miszerint a retinalis érsưrüség egészséges személyekben az életkorral csökken, szintén egyezik korábbi tanulmányok eredményeivel $[19,20]$. Megerósítettük továbbá, hogy a retinalis érhálózat sứrúsége a diabeteses retinopathia nélküli szemekben szignifikánsan csökkent a kontrollszemekben mért értékhez képest [21, 22]. Ugyanakkor elsőként írtuk le, hogy diabeteses betegekben a két szem közötti aszimmetria is szignifikánsan fokozott a kontroll egészséges személyek adataival összehasonlítva, továbbá hogy az aszimmetria mértéke független az általános rizikófaktoroktól, azt csak a diabetes fennállási ideje határozza meg. Véleményünk szerint eredményeink hasznosíthatók lehetnek a diabeteses betegek szürővizsgálatában, amennyiben ugyanis klinikailag detektálható diabeteses retinopathia nélküli cukorbetegeknél csökkent retinalis érsűrüség mellett fokozott két szem közötti aszimmetriát mérünk, akkor ezen betegek szorosabb követése javasolt a szemészeti szövődmények mielőbbi felismerése és kezelése céljából.

Ebben a vizsgálatban tervezetten minden részt vevő személy mindkét szemének adatait vizsgáltuk. Noha a szemészeti klinikai kutatásokban gyakori egy beteg egy szemének vizsgálata, egy személy mindkét szeméból származó adatok egyidejű vizsgálatával pontosabban jellemezhető egy olyan, progresszív és aszimmetrikus lefolyású betegség, mint a diabeteses retinopathia. További előnye a két szem szimultán vizsgálatának, hogy így egyszerre értékelhető a két szemet egyformán érintő szisztémás rizikófaktoroknak és az adott szemre jellemző paramétereknek, mint például a tengelyhossznak a hatása.

Tanulmányunkban a diabeteses csoportban szignifikánsan magasabb arányban fordult elő magas vérnyomás és dyslipidaemia, mint a kontrollcsoportban. Ugyanakkor ezen általános rizikófaktoroknak a hatását a többváltozós regressziós modellekben kontroll alatt tartottuk a 
szem tengelyhossza mellett, mely szintén befolyásolja az OCT-angiográfiás paraméterek értékét $[23,24]$.

A diabeteses retinopathia kialakulásában központi szerepe van az emelkedett vércukorértéknek, mely oxidatív stresszen keresztül proteinkináz C-aktivációhoz és glikációs végtermékek képződéséhez vezet [25-28] - ennek következménye a vascularis károsodások kialakulása [29, 30]. Diabeteses retinopathiában a retina fokozatosan csökkenő perfúziója a kapillárisok elzáródásával és körülírt ischaemiás területek megjelenésével jár, ami a fokozottan oxigén- és tápanyagigényes retinaszövet szerkezeti és múködési károsodását okozza [31]. Noha a vércukor- és a vérnyomáskontroll a legfőbb befolyásolható rizikófaktorok a DR megelőzéséhez, nem tisztázott, hogy a kisér-károsodás csökkentése milyen hatással van a diabeteses retinopathia progressziójának gátlására. Várható ugyanakkor, hogy a diabeteses retinopathia kialakulásának és progressziójának jobb megértése révén a jövőben újabb terápiák jelennek meg, melyek végső soron a DR okozta látásvesztés csökkenéséhez vezethetnek [32]. Ennek megfelelően a DR minél korábbi - akár a klinikai tünetek megjelenése előtti - diagnózisa előnyös lehet a későbbi szövődmények megelőzése szempontjából, így csökkentve a kezelés költségeit [33].

A diabetesszel összefüggő szemfenéki elváltozásokat ez idáig a látható érkárosodások meglétéhez kapcsolták. $\mathrm{Az}$ utóbbi években kifejlesztett OCT-angiográfiás technológia lehetővé teszi a retina mikrocirkulációjának kvalitatív és kvantitatív vizsgálatát [34, 35]. A módszernek - jó reprodukálhatóságának köszönhetően - a szemészet számos területén lehet jelentősége, mint például a diabeteses retinopathia, az időskori maculadegeneráció, a macularis teleangiectasia, a vénás keringészavarok és a glaucoma [36]. Ebben a vizsgálatban az OCT-angiográfiás felvételeket AngioVue készülékkel készítettük, amelyben a beépített AngioAnalytics szoftver lehetővé teszi a maculában a keringésben megtartott és a keringésből kiesett területek meghatározását és az érhálózat sűrüségének számszerüsítését. Az érhálózat-sưrüség számításának alapja az egységnyi területen mért kapilláriskeringésből kiesett terület aránya a teljes vizsgált területhez képest [19]. Ugyanakkor az OCT-angiográfia nem alkalmas az erekből történő folyadékszivárgás vizualizálására, és jelenleg nem képes a perifériás retinaterületek leképezésére sem [37]. Jelen tanulmányunkban a macula területén a felszíni kapillárisér-hálózat sưrüségét elemeztük, miután a mély kapillárisér-hálózat sűrüségének vizsgálata jelenleg még nem kellően megbízható a projekciós mütermékek miatt [38, 39].

Tanulmányunk gyengesége, hogy a betegeket egy szemészeti központban vizsgáltuk, ami megnehezítheti eredményeink általánosítását. Ugyanakkor a betegek száma és a szisztémás és a szemészeti rizikófaktorok egyidejü analízise alapján eredményeink kellően robusztusnak tekinthetők, és további vizsgálatok folytatására sarkallhatnak más kutatócsoportokat is. Továbbá, miután vizsgálatunk nem prospektív követéses vizsgálat volt, ered- ményeink alapján nem lehet egyértelmúen meghatározni az ok-okozati összefüggéseket a vizsgált rizikófaktorok és az OCT-angiográfiás paraméterek között. További gyengesége vizsgálatunknak, hogy nem állt rendelkezésünkre adat a betegek táplálkozási szokásairól, valamint társuló cardialis és nem cardialis betegségeikről, amelyek szintén szerepet játszthatnak a retinalis kisér-károsodásban. Noha ezek az információk segíthettek volna a rizikófaktorok és a retinalis kisér-károsodás közötti kapcsolat jobb megértésében, tanulmányunk elsődleges célja a diabeteses kisér-károsodás mértékének vizsgálata volt, hogy a szưrést és a progresszió követését hatékonyabbá tehessük.

Véleményünk szerint az a tény, hogy a két szem közötti aszimmetria fokozódása összefügg a diabetes fennállási idejével, alátámasztja azt a feltevést, hogy a DR progreszsziójának megítélése pontosítható, amennyiben a szisztémás rizikófaktorok vizsgálata mellett a retinalis érsűrüséget és annak két szem közötti különbségét is meghatározzuk. Ugyanakkor további követéses tanulmányok szükségesek ahhoz, hogy tisztázzuk a betegség fennállási ideje és a retinalis kisér-károsodás közötti összefüggést. A későbbiekben tervezett tanulmányaink megpróbálnak majd arra a kérdésre is választ adni, hogy a retinalis érsúrúség vizsgálatának van-e prediktív értéke az anti-VEGF- vagy a lézerkezelést követő terápiás válasz előrejelzésében.

Összefoglalásként kimutattuk, hogy diabeteses betegekben az érhálózat sürüsége csökkent a kontroll egészséges személyekkel összehasonlítva, továbbá fokozott a két szem közötti aszimmetria. Fontos megjegyezni, hogy a két szem közötti aszimmetria fokozódása csupán a diabetes fennállási idejétől függ, azt a diabeteses retinopathia egyéb, általános és szemészeti rizikófaktorai nem befolyásolják. Ezek az eredmények arra utalhatnak, hogy a már kezdetben is előrehaladottabb stádiumban lévő szemeken a diabeteses retinopathia progressziója idővel felgyorsulhat, ami miatt javasolt ezeknek a szemeknek a szoros ellenőrzése és minél korábbi kezelése. Továbbá, a csökkent érhálózat-sưrűség és a két szem közötti fokozott aszimmetria alkalmas lehet a diabeteses retinopathia igen korai, szemfenékvizsgálattal még nem detektálható formáinak a kiszűrésére, így segítve a terápia mielőbbi megkezdését.

Anyagi támogatás: A közlemény megírása, illetve a kapcsolódó kutatómunka anyagi támogatásban nem részesült.

Szerzői munkamegosztás: C. C., S. G. L., N. Z. Zs., K. I.: A vizsgálat tervezése. C. C., S. G. L., E. M., Sz. Zs., B. Á., R. M., P. A., R. Zs., H. H.: A vizsgálatok elvégzése. C. C., K. I.: Statisztikai elemzés, a közlemény megírása. N. Z. Zs:. Kritikai revízió. A cikk végleges változatát valamennyi szerző elolvasta és jóváhagyta.

Érdekeltségek: A szerzőknek nincsenek érdekeltségeik. 


\section{Irodalom}

[1] Wong TY, Cheung CM, Larsen M, et al. Diabetic retinopathy. Nat Rev Dis Primers 2016; 2: 16012; doi: 10.1038/ nrdp.2016.12.

[2] Tóth G, Szabó D, Sándor GL, et al. Diabetes and diabetic retinopathy in people aged 50 years and older in Hungary. $\mathrm{Br} \mathrm{J}$ Ophthalmol. 2017; 101: 965-969.

[3] Fenwick E, Pesudovs K, Rees G, et al. The impact of diabetic retinopathy: understanding the patient's perspective. $\mathrm{Br} \mathrm{J}$ Ophthalmol. 2011; 95: 774-782.

[4] Domján BA, Ferencz V, Tänczer T, et al. Large increase in the prevalence of self-reported diabetes based on a nationally representative survey in Hungary. Prim Care Diabetes 2017; 11: 107111 .

[5] Cunha-Vaz J, Ribeiro L, Lobo C. Phenotypes and biomarkers of diabetic retinopathy. Prog Retin Eye Res. 2014; 41: 90-111.

[6] Wong T, Klein K. The epidemiology of eye diseases in diabetes. In: Ekoé JM, Rewers M, Williams R, et al. (eds.) The epidemiology of diabetes mellitus (2nd edn). John Wiley and Sons, Oxford, 2008; pp. 475-497.

[7] Cheung N, Mitchell P, Wong TY. Diabetic retinopathy. Lancet 2010; 376: 124-136.

[8] Stratton I, Kohner E, Aldington S, et al. UKPDS 50: risk factors for incidence and progression of retinopathy in Type II diabetes over 6 years from diagnosis. Diabetologia 2001; 44: 156-163.

[9] The Diabetes Control and Complications Trial/Epidemiology of Diabetes Interventions and Complications Research Group. Retinopathy and nephropathy in patients with type 1 diabetes four years after a trial of intensive therapy. N Engl J Med. 2000; 342: 381-389.

[10] Holman R, Paul S, Bethel M, et al. Long-term follow-up after tight control of blood pressure in type 2 diabetes. $\mathrm{N}$ Engl J Med. 2008; 359: 1565-1576.

[11] International Council of Ophthalmology. ICO Guidelines for Diabetic Eye Care. Updated 2017. Available from: www.icoph. org/downloads/ICOGuidelinesforDiabeticEyeCare.pdf

[12] American Academy of Ophthalmology Retina/Vitreous Panel. Preferred Practice Pattern ${ }^{\circledR}$ Guidelines. Diabetic Retinopathy. American Academy of Ophthalmology, San Francisco, CA, 2016.

[13] Resch M, Németh C, Barcsay G, et al. Angiography of the ocular fundus without dye: Optical coherence tomography based angiography in exsudative age-related macular degeneration. [Szemfenéki érfestés festék nélkül: Az optikai koherencia tomográfia alapú angiográfia exsudativ típusú időskori maculadegenerációban.] Orv Hetil. 2016; 157: 1683-1690. [Hungarian]

[14] de Carlo TE, Romano A, Waheed NK, et al. A review of optical coherence tomography angiography (OCTA). Int J Retina Vitreous 2015; 1: 5; eCollection 2015.

[15] Hwang TS, Jia Y, Gao SS, et al. Optical coherence tomography angiography features of diabetic retinopathy. Retina 2015; 35 2371-2376

[16] Miwa Y, Murakami T, Suzuma K, et al. Relationship between functional and structural changes in diabetic vessels in optical coherence tomography angiography. Sci Rep. 2016; 6: 29064.

[17] Di G, Weihong Y, Xiao Z, et al. A morphological study of the foveal avascular zone in patients with diabetes mellitus using optical coherence tomography angiography. Graefes Arch Clin Exp Ophthalmol. 2016; 254: 873-879.

[18] Couturier A, Mane V, Bonnin S, et al. Capillary plexus anomalies in diabetic retinopathy on optical coherence tomography angiography. Retina 2015; 35: 2384-2391.

[19] Coscas F, Sellam A, Glacet-Bernard A, et al. Normative data for vascular density in superficial and deep capillary plexuses of healthy adults assessed by optical coherence tomography angiography. Invest Ophthalmol Vis Sci. 2016; 57: 211-223.

[20] Yu J, Jiang C, Wang X, Zhu L, et al. Macular perfusion in healthy Chinese: an optical coherence tomography angiogram study. Invest Ophthalmol Vis Sci. 2015; 56: 3212-3217.
[21] Dimitrova G, Chihara E, Takahashi H, et al. Quantitative retinal optical coherence tomography angiography in patients with diabetes without diabetic retinopathy. Invest Ophthalmol Vis Sci. 2017; 58: 190-196.

[22] de Carlo TE, Chin AT, Bonini Filho MA, et al. Detection of microvascular changes in eyes of patients with diabetes but not clinical diabetic retinopathy using optical coherence tomography angiography. Retina 2015; 35: 2364-2370.

[23] Sampson DM, Gong P, An D, et al. Axial length variation impacts on superficial retinal vessel density and foveal avascular zone area measurements using optical coherence tomography angiography. Invest Ophthalmol Vis Sci. 2017; 58: 3065-3072.

[24] Bazzazi N, Akbarzadeh S, Yavarikia M, et al. High myopia and diabetic retinopathy: A Contralateral eye study in diabetic patients with high myopic anisometropia. Retina 2017; 37: 12701276.

[25] Barile GR, Pachydaki SI, Tari SR, et al. The RAGE axis in early diabetic retinopathy. Invest Ophthalmol Vis Sci. 2005; 46: 2916-2924.

[26] Hudson BI, Schmidt AM. RAGE: a novel target for drug intervention in diabetic vascular disease. Pharm Res. 2004; 21 : 10791086.

[27] Stitt AW. The role of advanced glycation in the pathogenesis of diabetic retinopathy. Exp Mol Pathol. 2003; 75: 95-108.

[28] Antonetti DA, Barber AJ, Bronson SK, et al. Diabetic retinopathy: seeing beyond glucose-induced microvascular disease. Diabetes 2006; 55: 2401-2411.

[29] Antonetti DA, Lieth E, Barber AJ, et al. Molecular mechanisms of vascular permeability in diabetic retinopathy. Semin Ophthalmol. 1999; 14: 240-248.

[30] Miyamoto K, Khosrof S, Bursell SE, et al. Prevention of leukostasis and vascular leakage in streptozotocin-induced diabetic retinopathy via intercellular adhesion molecule-1 inhibition. Proc Natl Acad Sci USA 1999; 96: 10836-10841.

[31] Stitt AW, Curtis TM, Chen M, et al. The progress in understanding and treatment of diabetic retinopathy. Prog Retin Eye Res. 2016; 51: 156-186.

[32] The Diabetes Control and Complications Trial Research Group. The effect of intensive treatment of diabetes on the development and progression of long-term complications in insulin-dependent diabetes mellitus. N Engl J Med. 1993; 329: 977-986.

[33] Early Treatment Diabetic Retinopathy Study Research Group. Early photocoagulation for diabetic retinopathy. ETDRS report number 9. Ophthalmology 1991; 98: 766-785.

[34] Shahlaee A, Samara WA, Hsu J, et al. In vivo assessment of macular vascular density in healthy human eyes using optical coherence tomography angiography. Am J Ophthalmol. 2016; 165: $39-46$.

[35] Li J, Yang YQ, Yang DY, et al. Reproducibility of perfusion parameters of optic disc and macula in rhesus monkeys by optical coherence tomography angiography. Chin Med J (Engl). 2016; 129: $1087-1090$

[36] Jia Y, Wei E, Wang X, et al. Optical coherence tomography angiography of optic disc perfusion in glaucoma. Ophthalmology 2014; 121: 1322-1332.

[37] Kiss S, Berenberg TL. Ultra widefield fundus imaging for diabetic retinopathy. Curr Diab Rep. 2014; 14: 514.

[38] Zhang M, Hwang TS, Campbell P, et al. Projection-resolved optical coherence tomographic angiography. Biomed Opt Express 2016; 7: 816-828.

[39] Hwang TS, Zhang M, Bhavsar K, et al. Visualization of 3 distinct retinal plexuses by projection-resolved optical coherence tomography angiography in diabetic retinopathy. JAMA Ophthalmol. 2016; 134: 1411-1419.

(Kovács Illés dr., Budapest, Üllői út 26., 1085 e-mail: kovacsilles@yahoo.com) 